\title{
Measuring retail service quality: a replication study
}

\author{
Christo Boshoff* \\ Department of Business Management, University of Port Elizabeth, P.O. Box 1600. Port Elizabeth, 6000 Republic of South Africa \\ Nic S. Terblanché \\ Department of Business Management, University of Stellenbosch, Private Bag 5036, Stellenbosch, 7600 Republic of South Africa
}

Received September 1997

\begin{abstract}
In the recent past, few services marketing topics have attracted as much attention as the measuring and management of service quality. In this study an instrument developed in the United States of America, which measures the service quality in a South African retail environment, is empirically evaluated. The retail service quality instrument has been shown to be a valid and reliable instrument and the developers' claim of construct reliability can be supported.
\end{abstract}

Min onderwerpe in die veld van diensbemarking het in die onlangse verlede soveel reaksie ontlok as die meting en bestuur van diensgehalte. In die studie word ' $n$ instrument wat in die Verenigde State van Amerika ontwikkel is om die diensgehalte van kleinhandelaars te meet, onder Suid-Afrikaanse omstandighede empiries geëvalueer. Daar word bevind dat dié instrument betroubaar en geldig is en dat daar dus ondersteuning is vir die ontwikkelaars se aanspraak op konstrukgeldigheid.

*Author to whom correspondence should be addressed.

\section{Introduction}

Few research areas have attracted as much attention as service marketing in recent years. Much of this interest has centred on the controversy generated by the Service Quality Gaps Model proposed by Parasuraman, Zeithaml \& Berry (1985), and particularly the SERVQUAL instrument developed to measure service quality (Parasuraman, Zeithaml \& Berry, 1988).

Since the publication of SERVQUAL, a number of studies have used the instrument to measure service quality. In empirical assessment studies the SERVQUAL instrument has been severely criticized in terms of its convergent and discriminate validity, the use of difference scores and the use of negatively phrased items (Carman, 1990; Babakus \& Boller, 1992; Peter, Churchill \& Brown, 1993). Based partially on the findings of some of these studies, SERVQUAL was refined by Parasuraman, Berry \& Zeithaml (1991) who also provided a summary of empirical studies which have investigated the factor structure of SERVQUAL.

An interesting feature of the empirical studies, which have analysed SERVQUAL, is the wide variety of empirical factor structures obtained. These factor structures vary primarily in the number of interpretable factors, which consistently differed from the five-factor structure reported by Parasuraman et al. (1988; 1991). Cronin \& Taylor (1992), for instance, argued that SERVQUAL is unidimensional, while Babakus \& Boller (1992) reported a two-factor structure. A three-factor solution was reported by Schneider, Whecler \& Cox (1992) and Cliff \& Ryan (1994). Brensinger \& Lambert (1990) reported a four-factor solution. Six to eight empirical factors were reported by Carman (1990). Lately even the developers of the scale have produced evidence confirming the doubts expressed about the five-dimension configuration (Parasuraman, Zeithaml \& Berry, 1994: 211).

The considerable variation in empirical factor structures reported in the literature hampers our understanding of service quality and casts doubts over the use of the SERVQUAL instrument in future research. It also shows that a considerable amount of research still needs to be done concerning the dimensionality of service quality in general, and SERVQUAL in particular, as called for by its developers (Parasuraman et al., 1994: 221).

As service quality is a latent variable, which cannot be directly observed, it has to be measured indirectly. In an effort to measure the service quality of service industries Parasuraman et al. (1988) proposed the SERVQUAL instrument which consists of 22 perception items and 22 expectation items. Parasuraman et al. (1988) suggested that the differences between the client's expectations and perceptions represent service quality or the service quality gap (GAP 5). Furthermore, they suggested that five underlying dimensions (factors) influence service quality perceptions: tangibles, reliability, responsiveness, assurance and empathy.

Recently Dabholkar, Thorpe \& Rentz (1996) proposed an instrument based on SERVQUAL, which they suggest, measures service quality in a retailing environment. This instrument also captures, apart from the common dimensions that are likely to be shared by pure service environments and retail environments, additional dimensions of retail service quality relevant to the retail environment.

This study replicates their work and evaluates their retail service quality instruments' validity and reliability. If it is found to be valid and reliable in a South African context it will be the first such instrument available to measure the service quality of South African retailers.

\section{Service quality in a retail environment}

Dabholkar et al. (1996), deploring the lack of a theory-based approach to retail service quality measurement, addressed this limitation by means of a triangulation of research techniques. It consisted of interviews with several retail customers, indepth interviews with six customers and a qualitative study that monitored the thought process of three customers during an actual shopping experience. Based on these findings they propose a hierarchical factor structure for retail service quality assessment that consists of six first-order factors 
(dimensions), namely appearance, convenience, promises, doing it right, inspiring confidence and courteous/helpful; and five second-order factors (dimensions): physical aspects, reliability, personal interaction, problem solving and policy.

To test their proposed hierarchical model (Figure 1) Dabholkar et al. (1996) subjected four component models or special cases of the generalized model to four confirmatory factor analyses: a retail service quality model with only the five basic dimensions as first-order factors (Figure 2); a model with the five basic dimensions as first-order factors and service quality as a second-order factor (Figure 3); a model with the six sub-dimensions as first-order factors (Figure 4); and a model with the six sub-dimensions as first-order factors and corresponding dimensions as second-order factors (Figure 5).

Replicating these four models was one of the key objectives of this study (see Figures 1 to 5).

\section{Objectives}

Three research objectives were pursued. The first was to replicate their models using confirmatory factor analysis. The second was to evaluate the validity of the retail service quality instrument proposed by Dabholkar et al. (1996). The third was to assess the internal reliability of the overall scale as well as its underlying dimensions.

\section{Methodology}

Sample

The population was defined as active retail shoppers. The sample consisted of 352 hypermarket shoppers in a mall intercept-type situation. Personal interviews were conducted immediately after the completion of the shopping experience. Hypermarket shoppers were selected for analysis because they offer a mix of merchandise and service, while individual hypermarkets were identified on a convenience sampling basis.

\section{Data collection}

Shoppers were interviewed whilst they waited in a queue to pay for their goods. Interviews took place whilst queues were deep enough to allow for sufficient time to interview shoppers without interfering with their shopping. Shoppers were intercepted and interviewed as they lined up in the queue, which ensured randomness.

The rationale for the data collection method is based on the theory that respondents will be more attentive to the task of completing a questionnaire and will provide more meaningful responses when they are contextualized in the environment that they are evaluating. Further, being in the relevant environment, shoppers would be more likely to focus on dimensions of importance to them for evaluating the quality of

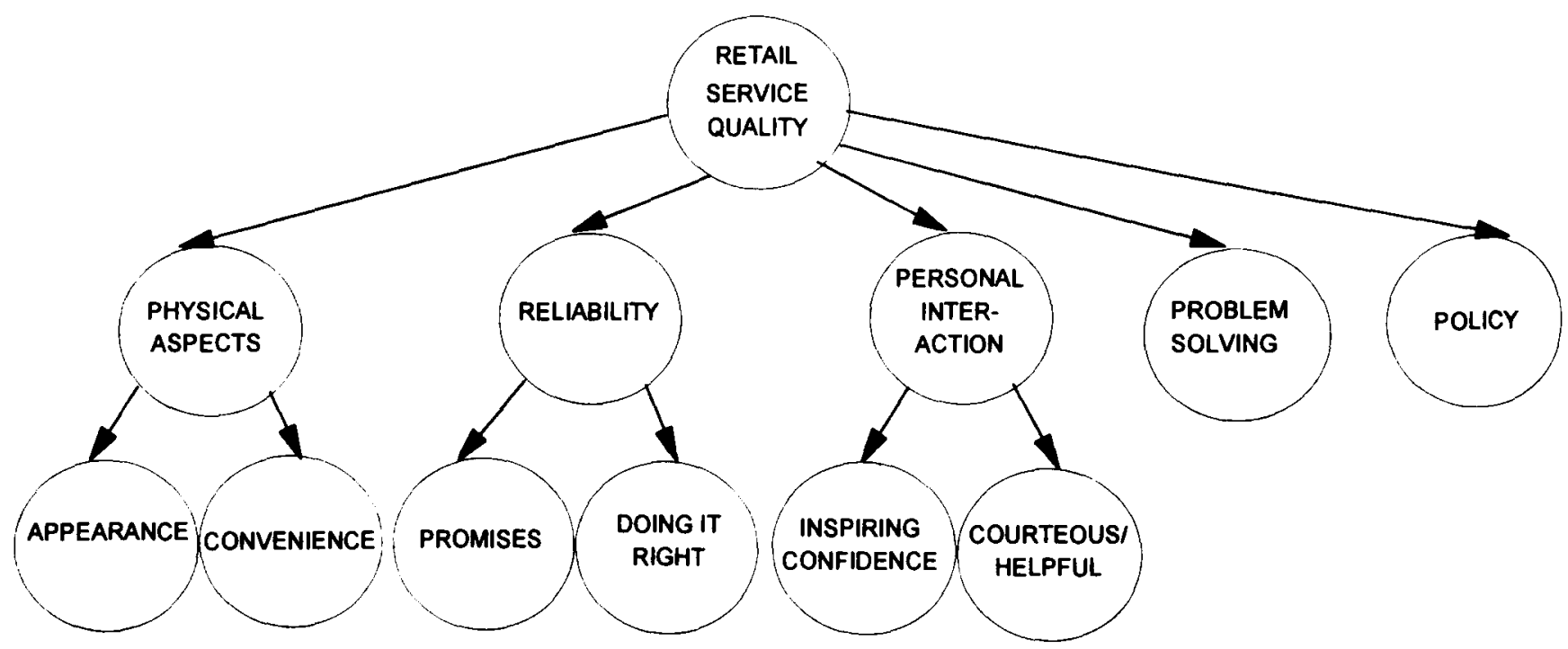

Figure 1 Proposed hierarchical structure for retail service quality

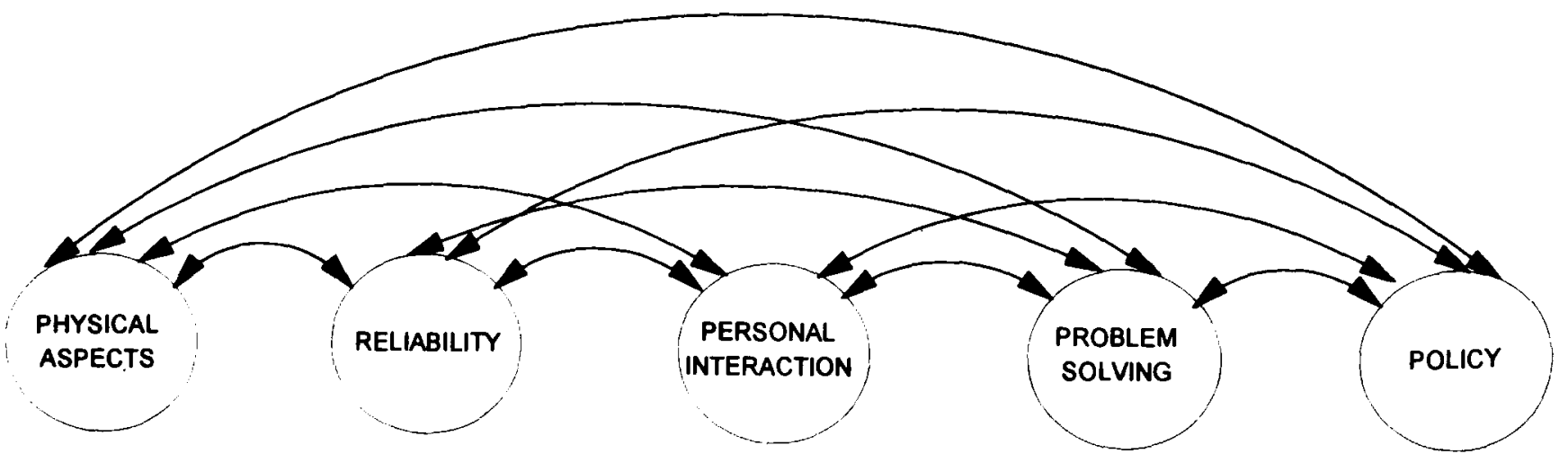

Figure 2 Retail service quality: the five basic dimensions 


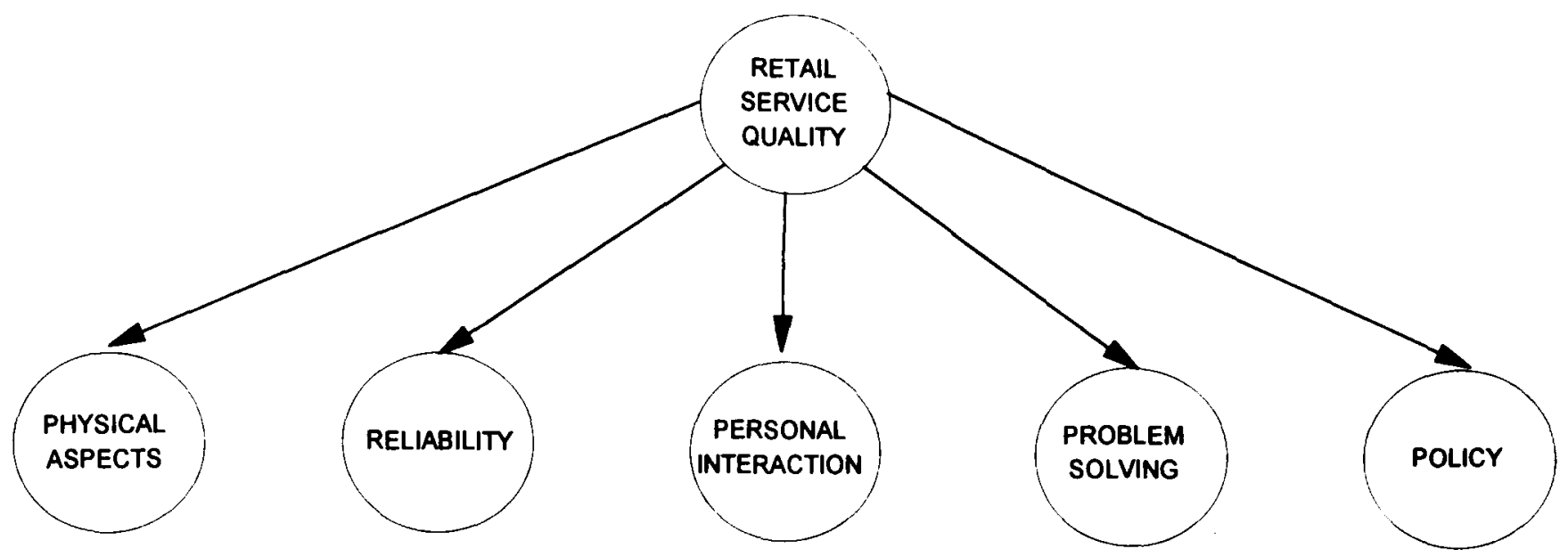

Figure 3 Retail service quality: service quality as a second-order factor to the five basic dimensions

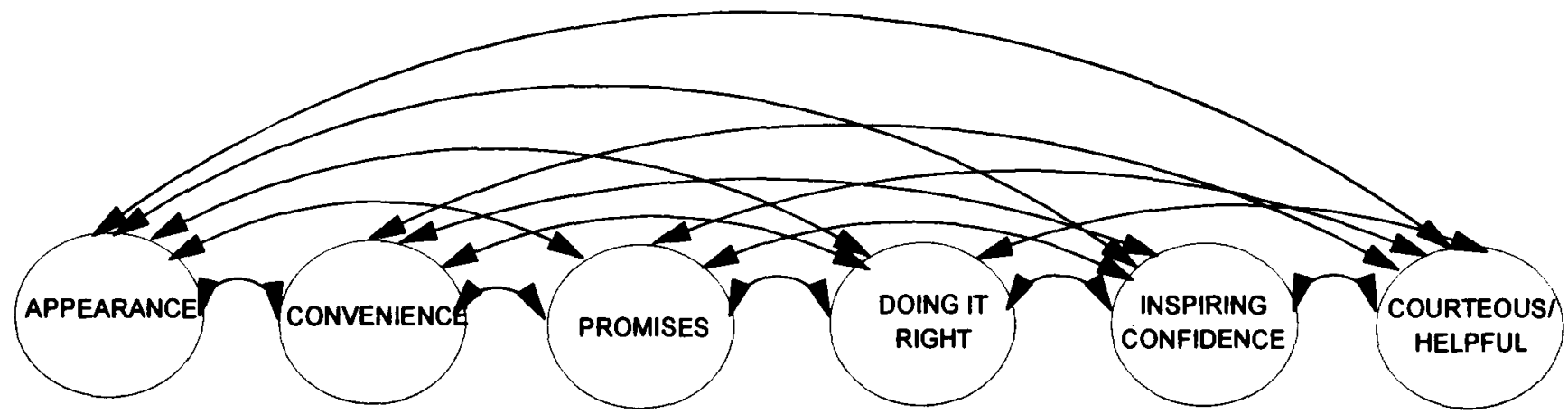

Figure 4 The six sub-dimensions as first-order factors

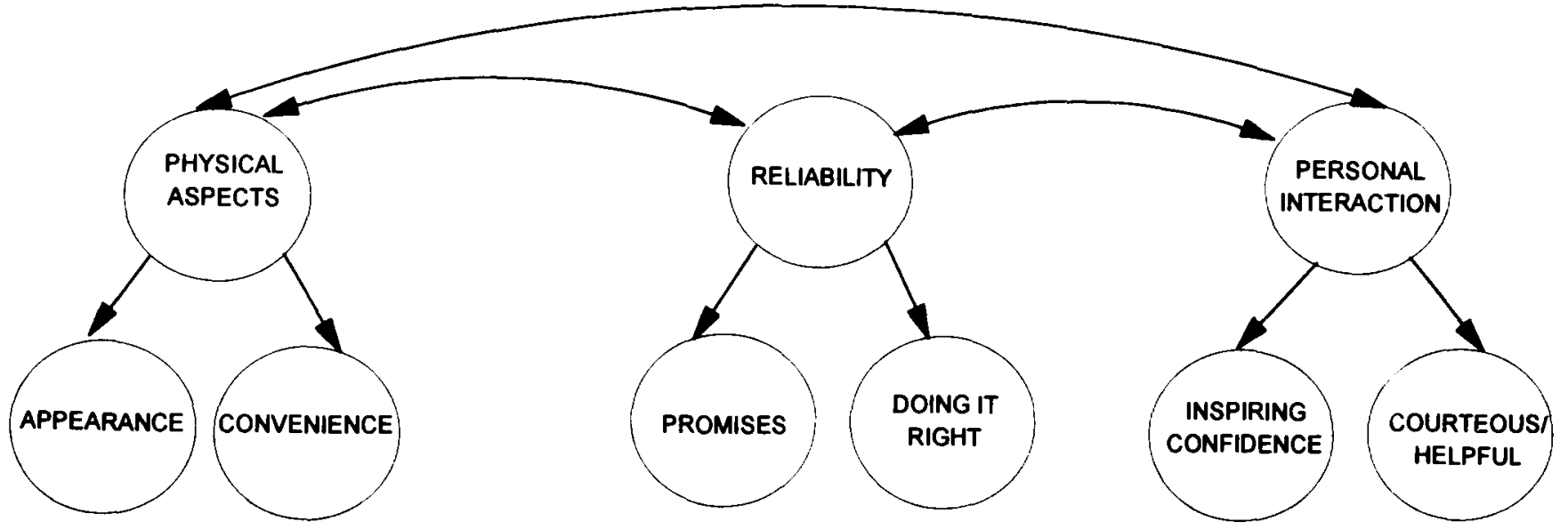

Figure 5 Retail service quality: the six sub-dimensions and three second-order factors

service at the shop (Dabholkar et al., 1996). Thirdly, it avoided problems associated with many similar techniques that require respondents to recall shopping experiences. Often these techniques generate questionable results as it is difficult to control for memory loss or lack of experience.

\section{Questionnaire}

The questionnaire consisted of 32 items. Seventeen items originate from the SERVQUAL scale to which Dabholkar et al. (1996) added eleven items. which they believe to be relevant to retailing specifically. The other four questions were added to assess the predictive, convergent and discriminate validity of the retail service quality questionnaire.

\section{Empirical results}

The first step in the data analysis phase of the study was to assess the validity of the retail service quality instrument.

\section{Validity results}

In an effort to assess the predictive validity of the retail service quality questionnaire respondents were asked whether they would continue to buy from this retailer again (VALI). Table 1 shows that the entire scale (SQUAL) and this item (VAL1) are highly correlated $(0.564 ; \mathrm{p}<0.0001)$. confirming its predictive validity. This strong positive correlation also holds for the individual underlying dimensions of the retail 


\begin{tabular}{|c|c|c|c|c|c|}
\hline & SQUAL & Physical & Reliable & Personal & Problems \\
\hline \multirow[t]{2}{*}{ SQUAL } & 1.000 & $0.84 !$ & 0.817 & 0.915 & 0.777 \\
\hline & & 0.0001 & 0.0001 & 0.0001 & 0.0001 \\
\hline \multirow[t]{2}{*}{ VALI } & 0.564 & 0.464 & 0.452 & 0.490 & 0.466 \\
\hline & 0.0001 & 0.0001 & 0.0001 & 0.0001 & 0.0001 \\
\hline \multirow[t]{2}{*}{ VAL2 } & 0.721 & 0.618 & 0.580 & 0.682 & 0.594 \\
\hline & 0.0001 & 0.0001 & 0.0001 & 0.0001 & 0.0001 \\
\hline \multirow[t]{2}{*}{ VAL3 } & -0.308 & -0.217 & -0.250 & -0.340 & -0.265 \\
\hline & 0.0001 & 0.0001 & 0.0001 & 0.0001 & 0.0001 \\
\hline
\end{tabular}

service quality construct. Respondents were also asked how they rated the overall service of the retail outlet (VAL2). According to Table 1 the correlation between this evaluation and the retail service quality questionnaire (SQUAL) is 0.721 ( $p<0.0001$ ), which confirms the convergent validity of the instrument. Again, this strong positive correlation also holds for the entire scale as well as for individual underlying dimensions of the retail service quality construct.

To assess the discriminate validity one further question was asked: 'How often have you complained about poor service at ...' (VAL3). If the responses to the retail service quality questionnaire (SQUAL) are negatively correlated with this item, it will confirm the discriminate validity of the instrument. Table 1 shows that not only SQUAL $(-0.308)$ but all the other underlying dimensions are significantly $(p<0.0001)$, negatively correlated to this question (VAL3), providing strong evidence of discriminate validity.

\section{Reliability results}

The next step was to evaluate the internal reliability of the instrument by means of Cronbach alpha coefficients.

Table 2 shows that the retail service quality scale proposed by Dabholkar et al. (1996) is a highly reliable instrument, returning an overall Cronbach alpha of 0.93 . The reliability of zach of the underlying dimensions is in all cases above the suggested minimum of 0.7 suggested by Peterson (1994) exsept for the Policy dimension, which returned a coefficient of ).68.

Zross-validation of the retail service quality instrument

The computer programme RAMONA (Browne \& Mels, 992) was used to establish whether or not the model prorosed in Figure 1 was supported by the data. A confirmatory actor analysis was performed on the correlation matrix. Table

\begin{tabular}{lc}
\hline Table 2 Reliability results \\
\hline Dimension & $\begin{array}{c}\text { Cronbach } \\
\text { alpha }\end{array}$ \\
\hline Physical aspects & 0.81 \\
Reliability & 0.76 \\
Personal interaction & 0.90 \\
Problem solving & 0.78 \\
Policy & 0.68 \\
Retail service quality scale & 0.93 \\
\hline
\end{tabular}

Table 3 Comparison of measures of fit of the retail service quality models

\begin{tabular}{|c|c|c|c|c|c|c|}
\hline MODEL & $X^{2}$ & RMSEA & AGFI & CFI & ECVI & RMSR \\
\hline \multicolumn{7}{|c|}{ Five basic dimensions of service quality as first-order factors (Figure 2) } \\
\hline Dabholkar et al. & 48.9 & N/A & 0.92 & 0.99 & $\mathrm{~N} / \mathrm{A}$ & 0.03 \\
\hline This study & 70.3 & 0.072 & 0.92 & 0.98 & 0.37 & 0.026 \\
\hline \multicolumn{7}{|c|}{$\begin{array}{l}\text { Five basic dimensions as first-order factors, service quality as second-order } \\
\text { factor (Figure 3) }\end{array}$} \\
\hline Dabholkar et al. & 59.1 & N/A & 0.90 & 0.98 & $\mathrm{~N} / \mathrm{A}$ & 0.03 \\
\hline This study & 127.9 & .096 & 0.87 & 0.96 & 0.51 & 0.045 \\
\hline \multicolumn{7}{|c|}{ Six sub-dimensions of service quality us first-order facturs (Figure 4) } \\
\hline Dabholkar et al. & 88.7 & N/A & 0.89 & 0.98 & $\mathrm{~N} / \mathrm{A}$ & 0.03 \\
\hline This study & 115.8 & 0.072 & 0.90 & 0.97 & 0.55 & 0.041 \\
\hline \multicolumn{7}{|c|}{$\begin{array}{l}\text { Six sub-dimensions of service quality as first-order factors corresponding } \\
\text { dimensions as second-order fuctors (Figure 5) }\end{array}$} \\
\hline Dabholkar et al. & 107.2 & N/A & 0.87 & 0.97 & $\mathrm{~N} / \mathrm{A}$ & 0.03 \\
\hline This study & 142.5 & 0.078 & 0.87 & 0.96 & 0.59 & 0.048 \\
\hline
\end{tabular}

3 compares the results of this analysis with those reported by Dabholkar et al. (1996).

The Root Mean Square Error of Approximation (RMSEA) value in Table 3 suggests a reasonable fit for the restricted factor analysis models in Figures 2, 4 and 5 (Browne \& Mels, 1990; Steiger \& Lind, 1980) but a poor fit for the model in Figure 3. All available indices compare favourably with those reported by Dabholkar et al. (1996). The best fitting model appears to be the five basic service quality dimensions as first-order factors (Figure 2) in both studies. The confirmatory factor analysis results reported in Table 3 suggest that the retail service quality instrument proposed by Dabholkar et al. (1996) demonstrates considerable construct validity (Tull \& Hawkins, 1995: 318). This contention is supported by the evidence of discriminant validity reported in Table 1 .

\section{Conclusion}

The retail service quality instrument has been shown to be a valid and reliable instrument to measure retail service quality in South Africa. The instrument is suitable for studying the service reality of retail businesses that offer a mix of services and goods, such as department stores, speciality stores and hypermarkets. It is useful for the gathering of data than can be used for benchmarking current levels of service quality, as well as periodic 'checks' to measure service quality. The instrument is also suitable for use as a diagnostic tool that will allow a retailer to identify areas of service delivery that are weak and in need of managerial attention. A further application as a diagnostic tool lies in the use of the instrument to analyse service quality at the overall level and the dimension level. Analysis of data at these different levels would allow evaluations of overall quality and dimension quality and would enable managers to identify problem areas within their shops, at the different levels (e.g. different geographical areas or different departments), and to concentrate resources on improving particular aspects of service quality. 


\section{Managerial implications}

Retail competition is intensifying. All forms of retail competition, namely intratype, intertype, vertical competition and systems competition show an accelerated pace at which retailers try to meet the needs of demanding consumers. Consumers are also, generally speaking, very aware of and well informed about new retailing formats that endeavour to satisfy their needs. Harsh economic times and other events tend to decrease loyalty as consumers' priorities increasingly centre on making ends meet.

For retailers this means that the dream of relationship retailing appears to be subject to more and more barriers that have to be overcome. It is accepted that the rendering of high quality service is a very useful means to differentiate the retail offer and attract support from consumers. The delivery of service, however, goes well beyond the traditional view of providing primary versus secondary or other classifications of service. Differentiation is much more complex. To render service that is truly a differentiating factor, the retailer must study the relationships between overall retail service quality and its underlying dimensions. The instrument considered in this study reveals that consumers could evaluate retail service quality according to five dimensions and, in addition, they may view overall service quality as a higher order factor and that some of the basic dimensions have sub-dimensions associated with them in the consumer's mind.

Retail management should therefore be well informed about the extent to which the shop's activities contribute to or detract from the overall or other dimensions of service quality. This requires continual measurement of all the levels of service rendering and the identification of areas of activity that are responsible for the standards of service quality. Only when these areas have been identified, will management be in a position to know whether staff training or changes to organization policy, or any other factor for that matter, require management attention.

For retail firms to establish or enhance their perceived service quality they will thus have to ensure that:

- all physical facilities that are used in service delivery are neat and modern-looking and that the store layout allows customers to find everything they need and move around with ease;

- they deliver their service's reliably by keeping all promises made (both implicitly and explicitly) and doing things right the first time;

- during all personal interaction between employees and customers the former are courteous and helpful and inspire confidence in customers;

- all problems customers experience are solved promptly including a proper system of returns and exchanges; and

- they have a store policy that is responsive to customer needs such as convenient store hours, parking and credit facilities.

The role that technology and particularly the Internet/ World-Wide Web will have on retailing needs to be considered. New technologies, interactive marketing and the like will open new opportunities for inventive marketers. These could be a serious threat to conventional retailing firms if they are used to circumvent traditional channel members such as retailers. Improved direct marketing is an obvious example.
Providing excellence in service delivery could be one way to overcome this threat by providing a personalized service tailored to the needs of individual consumers. The retail service quality instrument assessed in this study could be an excellent starting point to achieve that often elusive goal.

\section{References}

Babakus, E. \& Boller, G.W. 1992. An empirical assessment of the SERVQUAL scale, Journal of Business Research, 24: 253-268.

Brensinger, R.P. \& Lambert, D.M. 1990. Can the SERVQUAL scale be generalized to business-to-business services? Paper read at the Summer Marketing Educator's Conference, American Marketing Association.

Browne, M.W. \& Mels, G. 1990. RAMONA PC User's Guide. Pretoria: Human Sciences Research Council.

Browne, M.W. 1984. Asymptotically distribution free methods in the analysis of covariance structures, British Journal of Mathematical and Statistical Psychology, 37: 62-83.

Browne, M.W. 1982. Covariance structures. In Hawkins, D.M. ed. Topics in applied multivariate analysis. Cambridge: University Press.

Carman, J.M. 1990. Consumer perceptions of service quality: an assessment of the SERVQUAL dimensions, Journal of Retailing. 66(1): 33-55.

Cliff, A.\& Ryan, C. 1994. Do travel agencies measure up to customer expectation? An empirical investigation of travel agencies service quality as measured by SERVQUAL. Proceedings of the Tourism Down Under Conference. Massey University, Palmerston North, New Zealand, December: 553-578.

Cronir. J. J. \& Taylor, S.A. 1992. Measuring service quality: a re-examination and extension, Journal of Marketing, 56: 55-68.

Dabholkar, P.A., Thorpe, D.I. \& Rentz. J.O. 1996. A measure of service quality for retail stores: scale development and validation, Journal of the Academy of Marketing Science, 24(1): 3-16.

Frane, J., Jennrich, R.I. \& Sampson, P.F. 1990. 4M factor analysis. In Dixon, W.J. et al., eds. BMDP Statistical Software Manual, Vol. I. Berkeley: University of California Press.

Grönroos, C. 1990. Service management and marketing. Massachusetts : Lexington Books.

Jennrich, R.I. \& Sampson, P.F. 1966. Rotation for simple loadings, Psychometrika, 31: 313-323.

Lehtinen, U. \& Lehtinen, J.R. 1985. Service quality: a study of quality dimensions. Paper read at the Second World Marketing Congress, University of Stirling, Stirling, Scotland.

Parasuraman, A., Zeithaml, V.A. \& Berry, L.L. 1994. Alternative scales for measuring service quality: a comparative assessment based on psychometric and diagnostic criteria, Journal of Retailing, 70(3): 20l-230.

Parasuraman, A., Berry, L.L. \& Zeithaml, V.A. 1991. Refinement and reassessment of the SERVQUAL scale, Journal of Retailing, Vol 67(4): 420-450.

Parasuraman, A., Zeithaml, V.A. \& Berry, L.L. 1985. A conceptual model of service quality and its implications for future research, Journal of Marketing, 49(Fall): 4l-50.

Parasuraman, A.. Zeithaml, V.A. \& Berry, L.L. 1988. SERVQUAL: A multiple-item scale for measuring consumer perceptions of service quality, Journal of Retailing. 64(1): 12-40.

Peter, J., Churchill, G. \& Brown, T. 1993. Caution in the use of difference scores in consumer research, Journal of Consumer Re search, 19(March): 655-662. 
Peterson, R.A. 1994. A meta-analysis of Cronbach's Alpha, Journal of Consumer Research, 21(September): 381-391.

Satorra, A. \& Saris, W. E. 1985. Power of the likelihood ratio test in covariance structure analysis, Psychometrika, 50(1): 83-90.

Schneider, B., Wheeler, J.K. \& Cox, J.F. 1992. A passion for service: using content analysis to explicate service climate themes, Journal of Applied Psychology, 77(5): 705-716.

Steiger, J.H. \& Lind, J.C. 1980. Statistically based tests for the number of common factors. paper read at the Annual Meeting of the Psychometric Society, Iowa City.

Tull, D.S. \& Hawkins, D.I. 1993. Marketing research: measurement and method, 6th ed. New York: Macmillan. 